Kohl: A Journal for Body and Gender Research

Vol. 1, No. 1 (Summer 2015)

\title{
Pinkwashing: Israel's International Strategy and Internal Agenda
}

\author{
Ghadir Shafie
}


Over the past decade, Palestinian queer feminist activism has increased public awareness of Israel's use of "pinkwashing" in its desperate attempt to fight the growing Palestinian-led Boycott, Divestment and Sanctions (BDS) movement. Pinkwashing is a deliberate strategy used by Israel's government, agencies, and the Israeli LGBT community to exploit Israel's relatively progressive stance on gay rights, and to deflect international attention from its gross violations of human rights and international law. Israel's cynical use of gay rights aims to obfuscate the reality of occupation and apartheid. Queer BDS activists have therefore urged international queer groups to engage in solidarity actions with all Palestinians, and not confine their solidarity to Palestinian queers. In other words, Palestinian queer feminist activism, which views human rights in a holistic way, calls for and mobilizes active global solidarity around Palestine in general, through the lens of queer activism in the context of Israel/Palestine.

With regard to pinkwashing, Palestinian queer activism is invested in PinkWatching efforts to debunk Israel's pinkwashing propaganda. Israel's use of pinkwashing, among other whitewashing strategies, attempts to divert global attention from maintaining its oppressive regime of occupation, colonization and apartheid against Palestinians. Pinkwashing portrays a democratic, liberal and gay-friendly image of Israel, supported by its relatively gay-friendly laws. As a counterpoint to this idyllic picture of Israel, the pinkwashing campaign also aims to paint a racist and false image of the monolithically homophobic, backward and barbaric Arab/Palestinian.

One of the techniques Israel uses in its pinkwashing campaigns ${ }^{1}$ is to fabricate myths about "saving" Palestinian queers from their homophobic and oppressive families and communities by bringing them to live in Tel Aviv - the ultimate gay haven. Tel Aviv may be a gay heaven for Jewish Israeli citizens, or even for the hundreds of visitors who engage in gay tourism. However, it is neither friendly nor a haven for Palestinian LGBTs and queers.

As a teenager questioning my sexuality, I felt completely estranged and alone. Conversations about sexuality were non-existent, even among professionals working within schools. While school counselors and psychologists addressed controversial issues related to early marriage, domestic and street violence, and the abuse of drugs among teenagers, they refrained from addressing issues related to sexuality, sexual orientation and gender identity. Even gay literature in Arabic was rare, so I mostly read in Hebrew. Learning about sexual orientation and gender identity in a foreign language was in itself alienating.

The only means of communication available to me was a support line operated by an Israeli organization. After much debate, I called the line and the voice on the other end urged me to move to Tel Aviv. There, he assured me, I would live my life freely "as a lesbian." It was the first time anyone described me as such, even before I was able to define my own sexuality.

Despite this disconcerting drawback, the thought of moving to Tel Aviv accompanied me through my last years of school, and shortly after graduating, I applied to study at Tel Aviv University.

\footnotetext{
${ }^{1}$ Many of these campaigns are detailed in Sarah Schulman's book, Israel/Palestine and the Queer International, notably the "Brand Israel" campaign, documented in full in her Appendix "Brand Israel and Pinkwashing: A Documentary Guide."
} 
The move to Tel Aviv was overwhelming. There, I thought, I would explore my sexuality and live freely, without having to hide, to be closeted, to cease to exist in so many ways. I was introduced to early $90 \mathrm{~s}$ gay life in Tel Aviv through its vibrant bars and late-night gay parties, and made many gay Israeli friends. It didn't take long to realize that they were friendly to me as a lesbian while constantly trying to conceal, even suppress, my Palestinian identity. They affirmed that I did not look and sound Arab - so there was no need for me to embarrass them by bringing up my Palestinian-ness in conversations with others. I protested that my name clearly showed I was Arab. That was when they proposed changing my name for me.

I went home, feeling disgusted at the thought of being "renamed" by colonial oppressors to better fit their definition of the lesbian category of identity, and not offend their racial sensibilities. I had been a Palestinian Arab my entire life, who simply happened to question her sexuality. I had come to Tel Aviv to be who I was, but it became clear to me that I was welcome there as a "lesbian," not as a Palestinian. In their world of alleged "freedoms" and rights, there was no place for my Palestinian-ness. I had to choose between being "gay" and being Palestinian, but giving up a part of myself was impossible to bear. I had never experienced such rejection, and the thought of this exclusion made me sick of the Israeli LGBT scene.

At the end of my first year of university, I packed all my stuff and left Tel Aviv without saying my farewells, determined never to look back.

Just like the anonymous voice on the support line, the Israelis who tried to "save" and "help" me were forcing me instead into identifying with their normative, homogenizing LGBT scene. I had never expressed any belonging to that identity or lifestyle, and most importantly, I did not want to adhere to categories that denied me my political struggle.

After leaving Tel Aviv, I started associating lesbianism with "Jewishness," or even "Zionism," in opposition to being Palestinian. It took me years to be able to reconcile my same-sex desires and my Palestinianness. At the time, the term pinkwashing had not yet been coined in relation to Palestine ${ }^{2}$, but the practice was pervasive: coming out of the "closet" was already perceived as the pinnacle of the civilizing mission for Palestinian gays, and part of the coming out process also involved leaving their Arabness behind. I came to Aswat - Palestinian Gay Women in 2008. I was a Palestinian feminist activist working on the BDS campaign, and Aswat was just the space I had been looking for all of those years: a feminist queer group, committed to linking feminism, queerness and resistance to all forms of oppression - as Palestinians, as women, and as queers - and to bringing them together into one monumental struggle.

Throughout my years of work and activism at Aswat, I have learned that pinkwashing as a strategy is deeply rooted in the Israeli ideology of racism, hatred, and denial of Palestinian existence. It is not only a cynical exploitation of the issue of gay rights by Israel and its allies to divert global attention from Israel's

\footnotetext{
2 The word "pinkwashing" was first used by Ali Abunimah in 2010 to describe Israel's discriminatory practices, as Sarah Schulman mentioned in Israel/Palestine and the Queer International.
} 
constant and egregious violations of human rights and international law. It is also an internal political strategy to contain radical Palestinian dissent and keep Palestinians at a constant disadvantage. Thus when we talk about pinkwashing, we must remember our own experiences: the context and dynamics which have influenced our lives help us make sense of Israeli colonial and apartheid practices. Excluding Palestinians from the "gay haven" Tel Aviv - an experience many of us have been through - is merely symptomatic. Israel's pinkwashing policies run much deeper, functioning on a systemic level to alienate the "gay" Palestinian from their community, neutralize their potentially radical politics in favor of a bourgeois and domesticated "gay" identity, and thereby limit possibilities for radical change and mobilization in Palestinian societies. This internal strategy plays out through discriminatory rules and procedures, most notably, the unequal allocation of resources in favor of Israeli schools and LGBTQI organizations at the expense of Palestinian ones - especially in projects involving Palestinian citizens of Israel.

The pinkwashing strategy received a major boost in 2009, when an attack on an LGBT center in Tel Aviv sparked a flurry of activity and investment around the issue of LGBT rights, particularly in Jewish Israeli schools. The Ministry of Education allotted massive resources to Israeli LGBT organizations to create gay-friendly educational curricula and deliver workshops to students, mandated the commemoration of IDAHOT - International Day Against Homophobia and Transphobia - in all schools, and instituted obligatory diversity awareness training for teachers and other professionals working with young people. Palestinian schools, though they also fall within the scope of the Ministry of Education, were excluded from these efforts. Palestinian queer and LGBT organizations simply do not figure in the equation of LGBT resource distribution in Israel.

As part of this campaign, the Ministry of Education has been determinedly sabotaging all efforts made by Aswat - Palestinian Gay Women to provide professionals and service providers with training courses and study days on sexual rights and politics. In fact, over the past five years, the Ministry has been bent on excluding us from any project at all that aims to promote respect for diversity and tolerance within Palestinian societies.

Instead, the Israeli government and many foreign embassies in Tel Aviv - including the U.S. Embassy allocate funds to Israeli organizations to work with our constituencies in Palestinian communities. On the one hand, Jewish and foreign funding brands sexual rights as a "Zionist" issue, thus hindering even further the advancement of sexual freedoms in Palestinian societies. On the other, Israelis wanting to "educate" Palestinian about gay rights ensures that sexuality education is only delivered condescendingly by non-Palestinians to Palestinians, ignoring cultural, language, and other particularities.

The propaganda aspect of pinkwashing deems Palestinians not "civilized" enough to understand, let alone respect, "gay" rights, while at the same time depriving them access to equal resources and opportunities. For "gay" Palestinians, "coming out" in this environment restricts their sexual identities to the Israeli Jewish understanding of LGBT, even if and when the parameters of such a narrow spectrum do not apply to their local contexts. Pinkwashing is invested in maintaining backward, racist depictions of 
Palestinians in order to better justify oppression and unequal treatment of them, and its internal vicious cycle tokenizes "gay" Palestinians, who become not Palestinian enough in their own communities.

If anything, these policies and practices highlight the unequal dynamics of power in forcing identities in discriminated communities. It is therefore the moral duty of Palestinian activists speaking in international platforms to understand the dynamics behind Palestinian queer visibilities in our local contexts, and recognize pinkwashing as both an international strategy which concerns Israel's global brand, and an internal agenda that aims to divide and rule.

The unequal dynamics of power are manifested in every aspect of the lives of "gay" Palestinians and the broader social and political context which surrounds them. Riddled with illegal settlements and checkpoints, the current geopolitical configuration of Palestinian land restricts mobility across borders, even between neighboring villages, dividing Palestinians and containing the potential for mass mobilization. Israel's pinkwashing strategy alienates queer Palestinians even further from the struggle they share with other Palestinians. It attempts to draw them away from their families and friends, and into the orbit of self-proclaimed LGBT paradise Tel Aviv. The politically neutered discourse and lifestyle of "gay" identity and rights in the Israeli Jewish context offers an exciting insight: that Israel is desperately afraid of Palestinians organizing around the intersecting issues of occupation, apartheid, and sexual and gender-based oppression. Coupled with an effective BDS campaign endorsed in solidarity by international allies, recognizing pinkwashing as a deceptive and deeply colonial propaganda strategy that perpetuates the oppression of Palestinians will allow our queer and local movements to dismantle the structures of Israeli racism and occupation in Palestinian land. It is this kind of political organization that we must work for. 